\title{
Otimização da soroneutralização com diferentes tipos e subtipos de herpesvírus bovino e sua aplicação à epidemiologia*
}

\author{
CARINE LIDIANE HOLZ
}

\author{
Paulo Michel Roehe (Orientador - UFRGS)
}

Banca: Fernando Rosado Spilki (FEEVALE), Amauri Braga Simonetti (UFRGS), Cláudio Wageck Canal (UFRGS)

No presente estudo, buscou-se avaliar quais seriam as cepas de herpesvírus bovinos tipos 1 (BoHV-1) e 5 (BoHV-5) seriam mais adequadas para uso como vírus de confrontação em testes de soroneurtralização (SN). Oitocentas e dez amostras de soros de duas regiões geograficamente distintas foram avaliadas à SN frente a seis diferentes cepas virais, incluindo tipos e subtipos diversos (BoHV-1.1: EVI123/98 e Los Angeles; BoHV-1.2a: SV265/96; BoHV-5a: EVI88/95; BoHV-5b: A663 e BoHV-5c: ISO95/97). A maior sensibilidade foi revelada pelo somatório de soropositivos identificados com as seis cepas utilizadas no estudo. Uma combinação de quatro vírus (BoHV-1.1: LA e EVI123/98, BoHV-5a: EVI88/95 e BoHV-5b: A663) foi capaz de detectar $99,1 \%$ das amostras soropositivas. Estes quatro vírus foram selecionados para serem utilizados em um levantamento soroepidemiológico, com o intuito de estimar a prevalência das infecções causadas pelos BoHV-1 e BoHV-5 no Estado do Rio Grande do Sul. Para tanto, soros de 2200 fêmeas bovinas adultas (>24 meses), representativos da população bovina do Rio Grande do Sul, foram submetidos à SN frente às quatro cepas virais escolhidas. Com essa combinação, a soroprevalência média das infecções por BoHV-1 e BoHV-5 encontrada foi de 29,2\%. Além disso, analisando outros fatores que pudessem influenciar a prevalência das infecções, foram considerados fatores de risco o tipo de exploração corte, a ausência da prática de ordenha, o contato dos bovinos com ovinos/caprinos e animais silvestres, a venda de animais de reprodução, o uso de piquetes de parto/pós-parto, o uso de assistência veterinária privada e a criação de animais de raças europeias de corte. Os resultados obtidos no presente trabalho demonstraram que, para que a SN seja capaz de detectar animais soropositivos ao BoHV-1 e BoHV-5 com a máxima sensibilidade, o teste deve ser realizado com várias amostras de BoHV-1 e BoHV-5, não necessariamente de tipos ou subtipos diferentes, pois amostras do mesmo tipo de vírus apresentarrm diferentes sensibilidades. Além disso, as amostras de confrontação podem variar de acordo com a região geográfica de origem dos soros. Os resultados obtidos nesse levantamento revelam que anticorpos anti-BoHV-1 e anti-BoHV-5 encontram-se amplamente distribuidos nos rebanhos gaúchos. No entanto, não foi possível determinar a prevalência tipo-específica destas infecções com os testes realizados. Assim, a proporção de animais que estão infectados com o BoHV-1 ou com o BoHV-5 (ou ambos) na região examinada permanece desconhecida.

Descritores: herpesvírus bovino tipo 1, herpesvírus bovino tipo 5, soroneutralização, epidemiologia, fatores de risco.

Apresentada: 30 junho 2008

*Dissertação de Mestrado n. 506 (Especialidade: Virologia). 91f. Programa de Pós-graduação em Ciências Veterinárias [www.ufrgs.br/ppgcv]. Faculdade de Veterinária, Universidade Federal do Rio Grande do Sul (UFRGS), Porto Alegre/RS. CORRESPONDÊNCIA: C.L. Holz [carineholz@yahoo.com.br]. 


\title{
Serum neutralization optimization with different bovine herpesviruses types and subtypes and its epidemiology application**
}

\author{
CARINE LIDIANE HOLZ
}

\author{
Paulo Michel Roehe (Orientador - UFRGS)
}

Banca: Fernando Rosado Spilki (FEEVALE), Amauri Braga Simonetti (UFRGS), Cláudio Wageck Canal (UFRGS)

In this study a search was carried out to determine which of a number of available strains/isolates of bovine herpesviruses types 1 (BoHV-1) and 5 (BoHV-5) would be more suitable for use as challenge virus in serum neutralization (SN) tests. Eight hundred and ten bovine serum samples collected from two geographically distinct regions were evaluated in SN tests against six BoHVs of different types and subtypes (BoHV-1.1: EVI123/98 and Los Angeles; BoHV-1.2a: SV265/96; BoHV-5a: EVI88/95; BoHV-5b: A663 and BoHV-5c: ISO95/97). The highest sensitivity was achieved when the SN-positive sera obtained with the six different viruses were added. A combination of four viruses (BoHV-1.1 LA, and EVI123/98, BoHV5a EVI88/95 and BoHV-5b A663), was able to detect $99.1 \%$ of the seropositive samples. These four viruses were selected to carry out a seroepidemiological survey to estimate BoHV-1 and BoHV-5 prevalence in the state of Rio Grande do Sul. In order to achieve that, sera from 2,200 bovine female cows (>24 months-old), representative of the bovine population of Rio Grande do Sul state were tested on SN tests against the four selected viruses. With such combination, seroprevalence of BoHV-1 and BoHV-5 infections was 29.2\%.After examining potential factors that might affect the prevalence of such infections, the following were considered as significant risk factors: the type of exploitation (beef cattle $>$ dairy), use of milking procedures, concomitant presence of sheep, goats or wild animals in farm; sale of animals for reproductive purposes; use of pre and postparturition paddocks; use of private veterinary assistance and farming of European beef breeds. The results obtained here indicate that for the SN test to provide the highest sensitivity in detecting BoHV-1 and BoHV-5 seroposivive animals, it must be performed against a number of BoHV-1 and BoHV-5 strains, though not necessarily of different types and subtypes as viruses within a same subtype may display different sensitivities. Besides, challenge viruses may vary for geographically distinct areas. The serological survey performed with four distinct bovine herpesviruses reveal that antibodies to BoHV-1 and BoHV-5 are widely distributed among cattle flocks in Rio Grande do Sul. However, it was not possible to determine typespecific prevalence with the tests performed. Thus, the proportion of cattle actually infected with either BoHV-1 or BoHV-5 (or both) in the examined region remains undetermined.

Keywords: bovine herpesvirus type 1, bovine herpesvirus type 5, serum neutralization, epidemiology, risk factors.

**Master's Thesis \#506 (Field: Virology). 91p. Graduate Program in Veterinary Sciences [www.ufrgs.br/ppgcv]. Faculdade de Veterinária, Universidade Federal do Rio Grande do Sul (UFRGS), Porto Alegre/Brazil. CORRESPONDENCE: C.L. Holz [carineholz@yahoo.com.br]. 